\title{
KN-Journal of Cartography and Geographic Information, German Cartographic Society e.V. (DGfK), Society for Cartography and Geomatics: News
}

\section{Mark Vetter ${ }^{1}$ (D)}

Published online: 12 April 2020

(c) The Author(s) 2020

We are pleased to share with you the latest news from the society. This article is available in two forms. If you're accessing this article online then you can download it from the Electronical Supplementary Material which is attached to this article. In the print issue you can find the article at the back of this issue.

Acknowledgements Open Access funding provided by Projekt DEAL.

Open Access This article is licensed under a Creative Commons Attribution 4.0 International License, which permits use, sharing, adaptation, distribution and reproduction in any medium or format, as long as you give appropriate credit to the original author(s) and the source, provide a link to the Creative Commons licence, and indicate if changes were made. The images or other third party material in this article are included in the article's Creative Commons licence, unless indicated otherwise in a credit line to the material. If material is not included in the article's Creative Commons licence and your intended use is not permitted by statutory regulation or exceeds the permitted use, you will need to obtain permission directly from the copyright holder. To view a copy of this licence, visit http://creativecommons.org/licenses/by/4.0/.

Electronic supplementary material The online version of this article (https://doi.org/10.1007/s42489-020-00042-3) contains supplementary material, which is available to authorized users.

Mark Vetter

mark.vetter@fhws.de

1 Würzburg University of Applied Sciences, Würzburg,

Germany 